\title{
Evaluation of shelf-life of aonla (Emblica officinalis G.) cultivars during storage at room temperature
}

\author{
Poonam Kumari ${ }^{*}$, Archana Brar ${ }^{2}$ and Jitender Kumar ${ }^{1}$ \\ ${ }^{1}$ Department of Botany and Plant Physiology, CCS Haryana Agricultural University, Hisar-125004 (Haryana), INDIA \\ ${ }^{2}$ Department of Vegetable Science, CCS Haryana Agricultural University, Hisar-125004 (Haryana), INDIA \\ *Corresponding author. E-mail: poonamsanwal86@gmail.com
}

Received: July 19, 2016; Revised received: January 4, 2017; Accepted: February 22, 2017

\begin{abstract}
Five aonla cultivars viz. Chakaiya, Banarasi, Hathijhul, Krishna and Kanchan were evaluated for shelf-life during storage at room temperature. PLW increased with increase in the period of storage in all cultivars (0-15 days). There was no decay loss up to $6^{\text {th }}$ day of storage, however it was observed on $9^{\text {th }}$ day of storage in all the cultivars and it increased up to $15^{\text {th }}$ day of storage. Maximum PLW and decay loss was recorded in fruits of $\mathrm{cv}$. Banarasi $\left(8.14 \%\right.$ and $38.97 \%$, respectively) on $15^{\text {th }}$ day of storage whereas fruits of $\mathrm{cv}$. Chakaiya had minimum PLW and decay loss (5.83\% and $15.17 \%$, respectively) on same day of storage. Specific gravity and firmness decreased during the storage from 0-15 days in all the cultivars. Fruits of $\mathrm{cv}$. Banarasi had minimum specific gravity $(0.99)$ as well as firmness $\left(10.83 \mathrm{~kg} / \mathrm{cm}^{2}\right)$ whereas fruits of $c v$. Chakaiya had maximum specific gravity $(0.93)$ and firmness $\left(11.10 \mathrm{~kg} / \mathrm{cm}^{2}\right)$ at the end of the storage. The present experiment was conducted to evaluate the different cultivars of aonla fruit for their biochemical and physiological behavior under room temperature storage and to find out the best among five cultivars for their shelf life under the Haryana agro-climatic conditions.
\end{abstract}

Keywords: Aonla, Cultivars, Firmness, PLW, Specific gravity

\section{INTRODUCTION}

Aonla (Emblica officinalisG.) is an important crop indigenous to Indian subcontinent which is used in alternative medicine, health foods and herbal products. It is also found to be a rich source of ascorbic acid as compared to any other fruits (Karpagavalli et al., 2014). It belongs to the family Euphorbiaceae and comprises about 350 species (Hooker, 1973). Aonla has been cultivated in India since time immemorial. Aonla is being exported under the category of Ayurvedic and Unani herbs (Nayak et al., 2011). Although, the fresh fruit of aonla are consumed in very low quantity and major bulk of produce are being utilized for value addition, which has a pre-requisite for prolonged shelf-life to utilize it in food processing industry. Raw fruits are also used for making pickles, preserve like murabba. Recently, some more value-added products like supari, candy, segments in sugar syrup, churan and blended beverages of aonla juice with lime and ginger have also been prepared (Tandon et al., 2003). Thus, there is need to assess the storage potential of commercial cultivars for their better shelf-life. However, post harvest behaviour of aonla vary, depending on various factors viz; cultivar, rootstock, soil, agro-climatic conditions, growth and development pattern including flowering, fruiting, maturity, chemical composition of fruits as well as storage conditions. Aonla is one of the main constituent of many ayurvedic preparations like
Triphla and Chyawanprash. There is dearth of literature availability on physico-chemical properties of various Indian cultivars of aonla. The present investigation was therefore planned to evaluate the physicochemical properties and nutritional composition of five different varieties of aonla.

\section{MATERIALS AND METHODS}

Present investigations were carried out in post harvest laboratory of the Department of Horticulture and in Department of Botany and Plant Physiology, Chaudhary Charan Singh Haryana Agricultural University, Hisar. Fully mature aonla fruits of five cultivars namely Chakaiya, Banarasi, Hathijhul, Krishna and Kanchan of uniform size, color and free from blemishes were harvested from the orchard of the Horticulture department with the help of secateurs keeping small intact pedicel with each fruit. Two $\mathrm{kg}$ of fruits of each cultivar of aonla were packed in cardboard boxes with newspaper as cushioning material. Each box was treated as one replicate and all the treatments were replicated four times. Fruits were stored at room temperature.

Calculation of PLW (\%): Physiological loss in weight (PLW) was determined by weighing the fruits from three replicates at two days interval i.e. $3^{\text {rd }}, 6^{\text {th }}$, $9^{\text {th }} 12^{\text {th }}$ and $15^{\text {th }}$ day of observation and calculated by the following formula suggested by Srivastava and Tandon (1968). 
Physiological loss in weight $(\%)=$ Initial weight - final weight / Initial weight $\times 100$

Calculation of decay loss (\%): Fruits showing rotting due to micro organisms infection were considered as decayed ones and were weighed on each day of observation and were separated from the box. Weight of decayed fruits was taken on each day of observation. The percent decay loss was estimated by the following formula suggested by Srivastava and Tandon (1968).

Decay loss $(\%)=(\mathrm{W}-\mathrm{W}) / \mathrm{W} \times 100$

Where, $\mathrm{W}=$ Total weight of the fruits, $\mathrm{w}=$ Weight after eliminating decayed fruits

Calculation of specific gravity: Specific gravity was calculated by dividing the weight of the fruit with the volume of the same fruit.

Detemination of fruit firmness $\left(\mathrm{kg} / \mathrm{cm}^{2}\right)$ : Fruit firmness was calculated as the force required to puncture the fruit and was measured using pressure tester machine and expressed as $\mathrm{kg} / \mathrm{cm}^{2}$.

\section{RESULTS AND DISCUSSION}

Physiological loss in weight (PLW): Data depicted in table 1 indicates that physiological loss in weight increased with increasing period of storage i.e. from 0-15 days in all the cultivars at room temperature. Minimum PLW was observed in fruits of aonla $c v$. Chakaiya $n$ the initial day of storage i.e. $3^{\text {rd }}$ day $(0.80 \%)$ whereas maximum physiological loss in weight was observed in fruits of $c v$. Banarasi (1.43\%) on the same period of storage. Similar trend was observed during the period of storage and minimum PLW was observed in fruits of $c v$. Chakaiya in all days of storage i.e. from 0-15 days and

Table 1. Physiological loss in weight (\%) in fruits of aonla (Emblica officinalis G.) during storage in different cultivars at room temperature.

\begin{tabular}{lccccc}
\hline \multirow{3}{*}{ Cultivars (C) } & \multicolumn{5}{c}{ Physiological loss in weight (\%) } \\
\cline { 2 - 6 } & $\mathbf{3}$ & $\mathbf{6}$ & $\mathbf{9}$ & $\mathbf{1 2}$ & $\mathbf{1 5}$ \\
\cline { 2 - 6 } & 0.80 & 2.10 & 3.06 & 3.86 & 5.83 \\
Chakaiya & 1.43 & 2.50 & 3.76 & 4.76 & 8.14 \\
Banarasi & 1.33 & 2.34 & 3.46 & 4.23 & 6.56 \\
Hathijhul & 0.86 & 2.33 & 3.40 & 4.16 & 7.83 \\
Krishna & 1.20 & 2.11 & 3.56 & 4.66 & 7.50 \\
Kanchan & 0.17 & 0.27 & 0.38 & 0.39 & 0.41 \\
CD at 5\% & &
\end{tabular}

Table 2. Decay loss (\%) in fruits of aonla (Emblica officinalis G.) during storage in different cultivars at room temperature.

\begin{tabular}{lccc}
\hline \multirow{3}{*}{ Cultivars (C) } & \multicolumn{3}{c}{ Decay loss (\%) } \\
\cline { 2 - 4 } & \multicolumn{3}{c}{ Period of storage (D) } \\
\cline { 2 - 4 } & $\mathbf{9}$ & $\mathbf{1 2}$ & $\mathbf{1 5}$ \\
\hline Chakaiya & 0.29 & 3.53 & 15.17 \\
Banarasi & 4.13 & 21.07 & 38.97 \\
Hathijhul & 0.93 & 13.77 & 28.40 \\
Krishna & 0.37 & 4.07 & 21.99 \\
Kanchan & 0.73 & 9.40 & 23.30 \\
CD at 5\% & 0.25 & 2.00 & 3.05 \\
\hline
\end{tabular}

maximum PLW was recorded in fruits of $c v$. Banarasi on all days of storage. PLW in fruits is mainly due to various physiological processes i.e. respiration and transpiration (Singh et al., 2003). After harvesting of fruits, during storage, the supply of photosynthates from plant is cut off and whatsoever is stored inside the fruit has to be utilized for respiration, transpiration and other physiological processes. As all physiological processes utilizes various photosynthates already stored in fruits, as result of which fruit weight decreases during storage which is expressed in terms of PLW.

Variation in PLW in different cultivars is a genetic character of the varieties as different physiological processes go on at different rates in different cultivars. The variation in PLW among cultivars of aonla might also be attributed to variation in texture and skin characteristics of fruits (Singh et al., 2003). Similar variation in PLW has also been reported by Rahman et al. (2016) in different genotypes of strawberry and Balouchi et al. (2011) in broccoli cultivars during storage at room temperature.

Decay loss: No decay loss was observed up to $6^{\text {th }}$ day of storage in fruits of any of the cultivars of aonla. Decay loss increased from $9^{\text {th }}$ to $15^{\text {th }}$ day in all the cultivars during storage. On the $9^{\text {th }}$ day of storage, minimum decay loss was observed in fruits of $c v$. Chakaiya $(0.29 \%)$ followed by $c v$.Krishna $(0.37 \%)$ which was at par with each other whereas maximum decay loss was observed in $c v$. Banarasi which was $4.13 \%$ on same period of storage. Similar trend was observed on the $15^{\text {th }}$ day of storage where minimum decay loss was

Table 3. Specific gravity in fruits of aonla (Emblica officinalis G.) during storage in different cultivars at room temperature.

\begin{tabular}{lccccccc}
\hline & \multicolumn{6}{c}{ Specific gravity } & \multirow{2}{*}{ Mean } \\
\cline { 2 - 7 } Cultivars (C) & \multicolumn{6}{c}{ Period of storage (D) } & \\
\cline { 2 - 7 } & $\mathbf{0}$ & $\mathbf{3}$ & $\mathbf{6}$ & $\mathbf{9}$ & $\mathbf{1 2}$ & $\mathbf{1 5}$ & \\
\hline Chakaiya & 1.13 & 1.08 & 1.01 & 0.96 & 0.94 & 0.93 & 1.01 \\
Banarasi & 1.10 & 1.07 & 0.98 & 0.95 & 0.92 & 0.90 & 0.99 \\
Hathijhul & 1.11 & 1.07 & 0.99 & 0.96 & 0.94 & 0.91 & 1.00 \\
Krishna & 1.12 & 1.10 & 1.02 & 0.98 & 0.95 & 0.92 & 1.01 \\
Kanchan & 1.11 & 1.09 & 1.05 & 0.98 & 0.94 & 0.91 & 1.01 \\
Mean & 1.11 & 1.08 & 1.01 & 0.97 & 0.94 & 0.91 & \\
\hline
\end{tabular}

Table 4. Firmness $\left(\mathrm{kg} / \mathrm{cm}^{2}\right)$ in fruits of aonla (Embica officinalis G.) during storage in different cultivars at room temperature.

\begin{tabular}{lccccccc}
\hline & \multicolumn{6}{c}{ Firmness $\left(\mathbf{k g} / \mathbf{c m}^{2}\right)$} & \multirow{2}{*}{ Mean } \\
\cline { 2 - 7 } Cultivars & \multicolumn{6}{c}{ Period of storage (D) } \\
\cline { 2 - 7 } (C) & $\mathbf{0}$ & $\mathbf{3}$ & $\mathbf{6}$ & $\mathbf{9}$ & $\mathbf{1 2}$ & $\mathbf{1 5}$ & \\
\hline Chakaiya & 12.98 & 12.80 & 12.40 & 12.17 & 11.57 & 11.10 & 12.17 \\
Banarasi & 12.69 & 12.43 & 12.13 & 11.70 & 11.26 & 10.83 & 11.83 \\
Hathijhul & 12.78 & 12.50 & 12.17 & 11.75 & 11.23 & 10.93 & 11.89 \\
Krishna & 12.77 & 12.37 & 12.13 & 11.73 & 11.43 & 11.07 & 11.91 \\
Kanchan & 12.73 & 12.43 & 12.10 & 11.76 & 11.33 & 10.87 & 11.87 \\
Mean & 12.79 & 12.51 & 12.19 & 11.82 & 11.36 & 10.96 & \\
CD at 5\% & $\mathrm{C}=0.05$ & $\mathrm{D}=0.05$ & $\mathrm{CxD}=0.12$ & \\
\hline
\end{tabular}


observed in $c v$. Chakaiya $(15.17 \%)$ and maximum decay loss was observed in $c v$. Banarasi i.e. $38.97 \%$ followed by $c v$. Hathijhul $(28.40 \%)$ on the same day of storage. This might be due to the reason that different cultivars have different surfaces, texture and genetic characteristics. So attack of microflora might have been different in different cultivars of aonla. These results of increase in decay loss are in harmony with those obtained by Bishnoi and Sharma (2015) in guava and Gangwar et al. (2012) in different cultivars of aonla.

Specific gravity: Data presented in table 3 indicated the trend which has not been statistically analyzed because specific gravity has been calculated weight by volume method. As it is a calculated value so $C D$ has not been calculated. However, data predicted that specific gravity decreased during of storage. Among cultivars, maximum specific gravity was observed in fruits of $c v$. Chakaiya (1.01), $c v$. Krishna (1.01) and $c v$. Kanchan (1.01) whereas minimum specific gravity was observed in fruits of $c v$. Banarasi (0.99) on mean basis irrespective of storage period. Difference in specific gravity in different cultivars of aonla during storage is a varietal character. This is obvious as different cultivars have different rate of various physiological processes. As a result of which variation in weight and volume of different cultivars also varied. Results of these finding are in agreement with the reports of Singh et al. (2012) in mango, who also reported decreased in specific gravity in mango fruits during storage (0.90 to 0.86$)$.

Firmness: Firmness of aonla fruits was maximum at the initial period of storage i.e. 0 day (Table 4 ) in all the cultivars. Decrease in firmness of aonla fruits was observed with increasing period of storage as a result of which fruits of all cultivars retained minimum firmness on $15^{\text {th }}$ day of storage. Among the interactions, maximum firmness was observed in fruits of $c v$. Chakaiya $\left(12.98 \mathrm{~kg} / \mathrm{cm}^{2}\right)$ on initial period of storage which was retained on the $15^{\text {th }}$ day of storage in fruits of $c v$. Chakaiya $\left(11.10 \mathrm{~kg} / \mathrm{cm}^{2}\right)$ and $c v$. Krishna $\left(11.07 \mathrm{~kg} / \mathrm{cm}^{2}\right)$ which was at par with each other whereas minimum firmness was observed in fruits of $c v$. Banarasi $\left(12.69 \mathrm{~kg} / \mathrm{cm}^{2}\right)$ and $c v$. Kanchan $(12.73 \mathrm{~kg} /$ $\mathrm{cm}^{2}$ ) which was at par with each other on 0 day of storage which followed the similar trend up to $15^{\text {th }}$ day of storage and fruits of $c v$. Banarasi showed minimum firmness i.e. $10.83 \mathrm{~kg} / \mathrm{cm}^{2}$ followed by $c v$. Kanchan $\left(10.87 \mathrm{~kg} / \mathrm{cm}^{2}\right)$ on same day of storage. The decrease in firmness of aonla fruit may be due to gradual breakdown of protopectin and some other compound of higher molecular weight to lower molecular weight compounds which might have been more soluble in cytoplasm and this resulted in softening of the fruits (Afshar-Mohammadian and Rahimi-Koldeh 2010). These results are in harmony with those obtained by Banados et al. (2002) in different cultivars of raspber- ry, Parker and Maalekuu (2013) in tomato cultivars and Jha et al. (2010) and Jha et al. (2013) in mango hybrids and cultivars respectively, during storage.

\section{Conclusion}

The PLW and decay loss increased with the increase in storage period, whereas, both firmness and specific gravity were decreased. Among the five cultivars of aonla fruits of $c v$. Chakaiya had minimum PLW and decay loss during storage and maximum specific gravity as well as firmness whereas maximum PLW and decay loss was observed in fruits of $c v$. Banarasi during storage. From the findings, it can be concluded that $c v$. Chakaiya was the best among other five cultivars because it has higher shelf life then other and $c v$. Banarasi was poor in shelf life under Haryana agroclimatic conditions.

\section{REFERENCES}

Afshar-Mohammadian, M. and Rahimi-Koldeh, J. (2010). The comparison of carbohydrate and mineral changes in three cultivars of kiwifruit of northern Iran during fruit development. Australian Journal of Crop Science, 4:4954

Banados, M.P., Zoffoli, J.P., Soto, A. and Gonzalez, J. (2002). Fruit firmness and fruit retention strength in raspberry cultivars in chile. Acta Horticulture, 585:489493

Balouchi, Z., Peyvast, G.A., Ghasemnezhad M. and Saadatian, M. (2011). Changes of antioxidant compounds of broccoli (Brassica oleracea L. var. Italica) during storage at low and high temperatures. South Western Journal of Horticulture, Biology and Environment, 2:193-212

Bishnoi, C. and Sharma, R.K. (2015) Influence of storage temperature on decay loss and microbial quality of stored guava (Psidium Guajava L.). International Journal of Agriculture, Environment and Biotechnology, 8 (3): 621-624

Gangwar, S., Shukla, H.S., Katiyar, D. and Pandey, V. (2012). Effect of calcium nitrate on physiochemical changes and shelf life of aonla (Emblica officinalis Gaertn) fruits. HortFlora Research Spectrum, 1(3): 253258

Hooker, J. D. (1973). The flora of British India. Vol. VI. 1st Indian Reprint, Periodical Experts, Delhi.

Jha, S. K., Sethi, S., Srivastav, M., Dubey, A. K., Sharma, R. R., Samuel, D. V. K. and Singh, A. K. (2010) Firmness characteristics of mango hybrids under ambient storage. Journal of Food Engineering, 97:208-212

Jha, S.N., Jaiswal, P., Narsaiah, K., Kaur, P.P., Kumar, A. S. and Kumar, R. (2013). Textural properties of mango cultivars during ripening. Journal of Food Science and Technology, 50(6):1047-1057

Karpagavalli, B., Amutha, S., Padmini, T., Palanisamy, R. and Chandrakumar, K. (2014). Effect of processing on retention of antioxidant components in value added amla products. Indian Journal of Science and Technology, 7(5): 672-677

Nayak, P., Bhatt, D.K, Shukla, D.K. and Kumar, D. (2011) Evaluation of aonla (Emblica officinalis G.) segments- 
in-syrup prepared from stored fruits. Research Journal of Agricultural Science, 43(2): 252-257

Parker, R. and Maalekuu, B. K. (2013) The effect of harvesting stage on fruit quality and shelf-life of four tomato cultivars (Lycopersicon esculentum Mill). Agriculture and Biology Journal of North America, 4(3): 252-259

Rahman, M. M., Moniruzzaman, M., Ahmad, M. R., Sarker, B.C. and Alam, M.K. (2016). Maturity stages affect the postharvest quality and shelf-life of fruits of strawberry genotypes growing in subtropical regions. Journal of Saudi Society of Agricultural Sciences, 15: 28-37

Singh, P., Singh, M. K., Kumar, V., Kumar, M. and Malik, S. (2012). Effect of physico-chemical treatments on ripening behaviour and post-harvest quality of Amrapali mango (Mangifera indica L.) during storage. Journal of Environmental Biology, 33: 227-232

Singh, S., Singh, A. K. and Joshi, H. K. (2003). Storage behaviour of Indian gooseberry (Emblica officinalis G.) cultivars in semi-arid ecosystem of Gujarat. Indian Journal of Agricultural Research, 73: 530-534

Srivastava, M.P. and Tandon, D.K. (1968). Influence of temperature in Botryoplodia rot of citrus and Sapodia. Indian Phytopathology, 21: 195-197

Tandon, D. K., Kumar, S., Dixit, A., Yadav, R. C. and Sood, S. (2003). Processing potential of aonla. Paper presented at the National Seminar on Problems, Prospects and Utilization of aonla, Salem, Tamil Nadu, 8-10th July, 2003 